9. Kuo CC, Lin YF, Yao CT, Shih HC, Chung LH, Liao HC, et al. Tick-borne pathogens in ticks collected from birds in Taiwan. Parasit Vectors. 2017;10:587. https://doi.org/10.1186/ s13071-017-2535-4

10. Nichols Heitman K, Dahlgren FS, Drexler NA, Massung RF, Behravesh CB. Increasing incidence of ehrlichiosis in the United States: a summary of national surveillance of Ehrlichia chaffeensis and Ehrlichia ewingii infections in the United States, 2008-2012. Am J Trop Med Hyg. 2016;94:52-60. https://doi.org/10.4269/ ajtmh.15-0540

Address for correspondence: Pei-Yun Shu, Vector-Borne Viral and Rickettsial Diseases Laboratory, Center for Diagnostics and Vaccine Development, Centers for Disease Control, Ministry of Health and Welfare, No. 161, Kunyang St, Taipei 11561, Taiwan; email:pyshu@cdc.gov.tw

\section{Psittacosis Outbreak among Workers at Chicken Slaughter Plants, Virginia and Georgia, USA, 2018}

\author{
Kelly A. Shaw, ${ }^{1}$ Christine M. Szablewski, ${ }^{1}$ \\ Stephanie Kellner, Laura Kornegay, \\ Patricia Bair, Skyler Brennan, Audrey Kunkes, \\ Meredith Davis, Olivia L. McGovern, \\ Jonas Winchell, Miwako Kobayashi, \\ Nancy Burton, Marie A. de Perio, Julie Gabel, \\ Cherie Drenzek, Julia Murphy, \\ Caroline Holsinger, Laurie Forlano
}

Author affiliations: Centers for Disease Control and Prevention, Atlanta, Georgia, USA (K.A. Shaw, C.M. Szablewski,

O.L. McGovern, J. Winchell, M. Kobayashi); Virginia Department of Health, Richmond, Virginia, USA (K.A. Shaw, S. Kellner,

L. Kornegay, P. Bair, M. Davis, J. Murphy, C. Holsinger, L. Forlano); Georgia Department of Public Health, Atlanta (C.M. Szablewski, S. Brennan, A. Kunkes, J. Gabel, C. Drenzek); National Institute for Occupational Safety and Health, Cincinnati, Ohio, USA (N. Burton, M.A. de Perio)

DOI: https://doi.org/10.3201/eid2512.190703

During August-October, 2018, an outbreak of severe respiratory illness was reported among poultry slaughter plant workers in Virginia and Georgia, USA. A multiorganizational

${ }^{1}$ These authors contributed equally to this article. team investigated the cause and extent of illness, determined that the illness was psittacosis, and evaluated and recommended controls for health hazards in the workplace to prevent additional cases.

$\mathrm{P}$ sittacosis results from inhalation of aerosolized droppings or respiratory secretions of birds infected with Chlamydia psittaci. During 2008-2017, a total of 60 cases of psittacosis, a nationally notifiable disease in the United States, were reported to the National Notifiable Diseases Surveillance System (https://wwwn.cdc.gov/nndss).

The most common source of psittacosis in the United States is believed to be pet psittacine birds (e.g., parrots, cockatoos). The most recent large poultry-associated outbreaks in the United States were reported 3 decades ago and were linked to turkeys $(1,2)$. C. psittaci prevalence in poultry in the United States is unknown, although it has been recently identified in turkeys in the United States (3) and turkeys and chickens overseas $(4,5)$. Poultry can be infected but show no overt signs of illness (6).

During August 31-September 4, 2018, the Virginia Department of Health (VDH) received reports of 10 persons, all workers at the same chicken slaughter plant, hospitalized with fever, headache, cough, and radiographic evidence of pneumonia. Lower respiratory tract specimens (2 bronchoalveolar lavage and 1 sputum) from 3 hospitalized workers were positive for $C$. psittaci by real-time PCR targeting the C. psittaci locus tag CPSIT_RS01985 (7), performed at the Centers for Disease Control and Prevention (CDC; Atlanta, GA, USA). The Virginia plant suspended operations on September 8.

On September 12, the Georgia Department of Public Health (GDPH) was notified that 3 employees of a Georgia chicken slaughter plant owned by the same company were hospitalized with pneumonia. C. psittaci was detected in sputum samples from all 3 patients. The Georgia plant suspended operations on September 15.

After plant closures, VDH and GDPH staff inspected the respective plants, which both slaughter only chickens, and collected environmental samples to test for C. psittaci. Staff collected samples from areas where workers were close to or directly handled live chickens or carcasses. Environmental samples were tested for chlamydial species by using real-time PCR, followed by high-resolution melt analysis (8), at the University of Georgia Infectious Disease Laboratory (Athens, GA, USA).

The company held employee meetings in each state and invited VDH and GDPH representatives to provide outbreak information and conduct active case finding. VDH and GDPH initiated investigations of cases and potential risk factors. A case was defined as illness in a worker employed during August 1-September 7, 2018, at the 
Virginia plant, or during August 13-September 28, 2018, at the Georgia plant, who had either physician-diagnosed pneumonia, or fever or chills with $\geq 2$ symptoms of headache, cough, or muscle aches. A confirmed case required PCR detection of $C$. psittaci in a clinical specimen.

At the Virginia plant, 50 cases (including 5 confirmed) were identified; 30 cases (including 8 confirmed) were identified at the Georgia plant. PCR cycle threshold values for the 13 confirmed cases ranged from 26 to 37 . Using sequencing of the outer membrane protein $\mathrm{A}$ (ompA) gene, we identified genotype $\mathrm{D}$ of $C$. psittaci in patient specimens; this genotype is most often found in poultry $(4,5)$. Cases occurred during August 3-September 8 in Virginia and August 17-October 22 in Georgia.

We provide detailed characteristics for all patients (ill workers) (Table). A total of $58 \%$ of patients were men (age range 19-58 years). Bird evisceration was the most common job duty or title (reported by $53 \%$ of ill workers), consistent with previous psittacosis outbreaks $(1,2,9,10)$. Twenty-nine workers were hospitalized (3 in intensive care) and had stays from 1 to 37 days. No deaths were reported.

C. psittaci was not detected in any of the environmental samples from the Virginia $(\mathrm{n}=62)$ and Georgia $(\mathrm{n}=$ 46) plants. After extensive cleaning with sanitizers, including quaternary ammonia, chlorine solutions, and chlorine dioxide foam (all registered by the US Environmental Protection Agency as effective against C. psittaci), the Virginia and Georgia plants reopened on September 18 and 19 , respectively. Georgia cases that occurred after the plant reopened were attributed to longer incubation periods. The incubation period for psittacosis is typically 1-4 weeks (6), but illness onset $>30$ days after exposure was reported in the 2 most recent poultry-associated outbreaks in the United States $(1,2)$.

At the request of the US Department of Agriculture Food Safety and Inspection Service, the National Institute for Occupational Safety and Health conducted a health hazard evaluation of the Virginia plant on September 19-20. Recommendations to the plant included repositioning cooling fans, ensuring evisceration tools were working properly, and changes to other work practices to reduce bacterial contamination and aerosolization. A health hazard evaluation was not requested at the Georgia plant, but company management reported implementing or evaluating options to implement all applicable recommendations at the plants.

Clinicians evaluating poultry slaughter plant workers with febrile respiratory illness should consider psittacosis as a possible diagnosis. In the absence of a more likely diagnosis, clinicians should contact state health authorities to discuss whether $C$. psittaci testing should be requested through CDC, which has the only laboratory in the United States in which PCR testing for human specimens is currently available.

\section{About the Authors}

Dr. Shaw is a CDC Epidemic Intelligence Service officer at the Virginia Department of Health, Richmond, VA. Her primary research interest is applying data to improve public health knowledge and practice.

Table. Characteristics of chicken slaughter plant workers tested during outbreak of psittacosis, Virginia and Georgia, United States, 2018

\begin{tabular}{|c|c|c|c|}
\hline \multirow[b]{2}{*}{ Characteristic } & \multicolumn{3}{|c|}{ No. (\%) workers } \\
\hline & Confirmed, $n=13$ & Other, $\mathrm{n}=67$ & All, $\mathrm{n}=80$ \\
\hline \multicolumn{4}{|l|}{ Sex } \\
\hline M & $10(77)$ & $36(54)$ & $46(58)$ \\
\hline $\mathrm{F}$ & $3(23)$ & $31(46)$ & $34(42)$ \\
\hline \multicolumn{4}{|l|}{ Symptoms } \\
\hline Fever & $13(100)$ & $57(85)$ & $70(88)$ \\
\hline Cough & $11(85)$ & $52(78)$ & $63(79)$ \\
\hline Muscle aches & $10(77)$ & $47(70)$ & $57(71)$ \\
\hline Headache & $9(69)$ & $59(88)$ & $68(85)$ \\
\hline Chills & $9(69)$ & $51(76)$ & $60(75)$ \\
\hline Gastrointestinal* & $6(75)$ & $13(59)$ & $19(63)$ \\
\hline \multicolumn{4}{|l|}{ Clinical } \\
\hline Radiologically confirmed pneumonia & $13(100)$ & $30(45)$ & $43(54)$ \\
\hline Hospitalized & $11(85)$ & $18(27)$ & $29(36)$ \\
\hline Intensive care & $3(23)$ & 0 & $3(4)$ \\
\hline \multicolumn{4}{|l|}{ Job duties $†$} \\
\hline Evisceration & $8(62)$ & $34(51)$ & $42(53)$ \\
\hline Live-bird handling & $3(23)$ & $6(9)$ & $9(11)$ \\
\hline Cleaning & $2(15)$ & $5(7)$ & $7(9)$ \\
\hline Packing or shipping & $1(8)$ & $13(19)$ & $14(18)$ \\
\hline Inspection or quality assurance & $1(8)$ & $6(9)$ & $7(9)$ \\
\hline Other $\ddagger$ & 0 & $5(7)$ & $5(6)$ \\
\hline
\end{tabular}


Dr. Szablewski is a CDC Epidemic Intelligence Service officer at the Georgia Department of Public Health, Atlanta, GA. Her primary interest is acute disease epidemiology.

\section{References}

1. Centers for Disease Control. Psittacosis at a turkey processing plant-North Carolina, 1989. MMWR Morb Mortal Wkly Rep. 1990;39:460-1, 467-9.

2. Hedberg K, White KE, Forfang JC, Korlath JA, Friendshuh KA, Hedberg CW, et al. An outbreak of psittacosis in Minnesota turkey industry workers: implications for modes of transmission and control. Am J Epidemiol. 1989;130:569-77. https://doi.org/ 10.1093/oxfordjournals.aje.a115371

3. Shivaprasad HL, Carnaccini S, Bland M, Aaziz R, Moeller R, Laroucau K. An unusual outbreak of chlamydiosis in commercial turkeys involving the nasal glands. Avian Dis. 2015;59:315-22. https://doi.org/10.1637/11006-123014-Reg

4. Dickx V, Geens T, Deschuyffeleer T, Tyberghien L, Harkinezhad T, Beeckman DS, et al. Chlamydophila psittaci zoonotic risk assessment in a chicken and turkey slaughterhouse. J Clin Microbiol. 2010;48:3244-50. https://doi.org/10.1128/ JCM.00698-10

5. Lagae S, Kalmar I, Laroucau K, Vorimore F, Vanrompay D. Emerging Chlamydia psittaci infections in chickens and examination of transmission to humans. J Med Microbiol. 2014;63:399-407. https://doi.org/10.1099/jmm.0.064675-0

6. Heymann D, editor. Control of communicable diseases manual, 20th ed. Washington: American Public Health Association; 2015.

7. Wolff BJ, Morrison SS, Winchell JM. Development of a multiplex TaqMan real-time PCR assay for the detection of Chlamydia psittaci and Chlamydia pneumoniae in human clinical specimens. Diagn Microbiol Infect Dis. 2018;90:167-70. https://doi.org/ 10.1016/j.diagmicrobio.2017.11.014

8. Mitchell SL, Wolff BJ, Thacker WL, Ciembor PG, Gregory CR, Everett KD, et al. Genotyping of Chlamydophila psittaci by real-time PCR and high-resolution melt analysis. J Clin Microbiol. 2009;47:175-81. https://doi.org/10.1128/JCM.01851-08

9. Rindge ME, Jungherr EL, Scruggs JH. Serologic evidence of occupational psittacosis in poultry-plant workers. N Engl J Med. 1959;260:1214-8. https://doi.org/10.1056/NEJM195906112602404

10. Laroucau K, Aaziz R, Meurice L, Servas V, Chossat I, Royer H, et al. Outbreak of psittacosis in a group of women exposed to Chlamydia psittaci-infected chickens. Euro Surveill. 2015;20:21155. https://doi.org/10.2807/1560-7917. ES2015.20.24.21155

Address for correspondence: Kelly A. Shaw, Virginia Department of Health, 109 Governor St, Office 531, Richmond, VA 23219, USA; email: nrb7@cdc.gov

\section{Effectiveness of Immune Checkpoint Inhibitors in Transplant Recipients with Progressive Multifocal Leukoencephalopathy}

\author{
Chloé Medrano, François Vergez, \\ Catherine Mengelle, Stanislas Faguer, \\ Nassim Kamar, Arnaud Del Bello
}

\begin{abstract}
Author affiliations: Hôpital Rangueil, Toulouse, France
(C. Medrano, S. Faguer, N. Kamar, A. Del Bello); Université

Paul Sabatier, Toulouse (C. Medrano, F. Vergez, S. Faguer,

N. Kamar, A. Del Bello); Hôpital de Toulouse, Toulouse (F. Vergez,

C. Mengelle); Hôpital Purpan, Toulouse (C. Mengelle, N. Kamar,

A. Del Bello)
\end{abstract}

DOI: https://doi.org/10.3201/eid2511.190705

Antibodies against PD1 have been used to treat progressive multifocal leukoencephalopathy (PML), a rare brain disease caused by JC virus. We used these antibodies (nivolumab) to treat PML in 3 kidney transplant recipients. All died within 8 weeks of diagnosis. Hence, nivolumab did not improve PML outcome after solid organ transplantation.

$\mathrm{T}^{\mathrm{s}}$ he role of T-cell exhaustion in the development of progressive multifocal leukoencephalopathy (PML), a rare brain disease caused by JC virus, has prompted clinicians to use immune checkpoint inhibitor molecules to treat JC virus-infected patients. Recently, Cortese et al. (1) used antibodies against PD1 to treat PML in 8 patients $(6$ with a history of blood disorders and 2 with HIV infection). They noted improvement or stabilization of symptoms for $5 \mathrm{pa}-$ tients but no benefit for the others.

Since 2017, we have treated PML in 3 kidney transplant recipients with a definitive diagnosis, according to the American Academy of Neurology (https://www.aan.com) consensus, made 5 (range 2-17) years after transplantation. We have compiled clinical and radiologic findings for these patients (Appendix Figures 1-3, https://wwwnc.cdc.gov/ EID/article/25/11/19-0705-App1.pdf). Since transplantation, the patients had been receiving mycophenolic acid and steroids with either belatacept $(n=1)$ or tacrolimus $(n=2)$. At PML diagnosis, immunosuppressants were immediately withdrawn, and nivolumab (antibodies against PD1) was given at a dose of $3 \mathrm{mg} / \mathrm{kg}$ every 15 days (2 injections for 2 patients and 3 injections for 1) (Table). For the patient who had received belatacept, we performed 3 apheresis sessions to remove the drug before nivolumab initiation. All patients died within the first 8 weeks after PML diagnosis because of rapid progression of neurologic symptoms. 